\title{
Integrated Study on Pulse Diagnosis of TCM and Cardiology by Analyzing the Distribution Characteristics of Atherosclerosis Parameters at Six Positions of Cunkou
}

Keywords:

Posted Date: April 12th, 2021

DOI: https://doi.org/10.21203/rs.3.rs-197430/v2

License: (c) (i) This work is licensed under a Creative Commons Attribution 4.0 International License. Read Full License 


\section{Abstract}

The authors have requested that this preprint be removed from Research Square. 